J. Lake Sci. (湖泊科学), 2014, 26(1):9-18

http : //www. jlakes. org. E-mail : jlakes@niglas.ac.cn

(c) 2014 by Journal of Lake Sciences

\title{
水生生态系统蓝藻固氮作用研究进展与展望
}

\author{
叶琳琳 $^{1,2}$, 张 民 ${ }^{2}$, 孔繁翔 ${ }^{2 * *}$, 阳 振 $^{2}$, 史小丽 ${ }^{2}$, 间德智 ${ }^{1}$, 刘 波 $^{1}$ \\ ( 1 : 南通大学地理科学学院, 南通 226007) \\ (2: 中国科学院南京地理与湖泊研究所湖泊与环境国家重点实验室,南京 210008)
}

摘 要: 固氮蓝藻在水生生态系统中占优势是由多种因素所引起的, 如营养盐浓度及形态、氮磷比、水温和微量元素等. 一般认为, 湖泊中正磷酸盐浓度 $\geqslant 0.01 \mathrm{mg} / \mathrm{L}$ 、溶解性无机氮浓度 $\leqslant 0.1 \mathrm{mg} / \mathrm{L}$ 时, 固氮蓝藻出现, 并且低的氮磷比是表征 水体中固氮蓝藻出现的重要指标, 但引起固氮与非固氮蓝藻分异的驱动机制还需要深人研究. 此外, 光照、无机氮浓度与 形态、异形胞丰度和溶解性有机物对蓝藻固氮速率有重要影响, 进而决定蓝藻氮释放通量及对水体中氮库的贡献作用. 固氮蓝藻是贫营养盐海域和海洋生态系统中氮库的重要贡献者, 但在富营养化湖泊中, 其贡献作用还存在争议. 因此就 目前国内外对固氮蓝藻相关研究做综述, 以期待业界同行能够对蓝藻固氮作用及其氮释放对水生生态系统中氮循环的 贡献引起重视.

关键词: 固氮蓝藻;固氮速率;氮库;水生生态系统

\section{Progress and prospect of research on cyanobacteria nitrogen fixing in aquatic ecosystem}

\author{
YE Linlin ${ }^{1,2}$, ZHANG Min², KONG Fanxiang ${ }^{2}$, YANG Zhen ${ }^{2}$, SHI Xiaoli ${ }^{2}$, YAN Dezhi ${ }^{1} \&$ LIU Bo $^{1}$ \\ (1: Geographical Sciences College, Nantong University, Nantong 226007, P. R. China) \\ (2: State Key Laboratory of Lake Science and Environment, Nanjing Institute of Geography and Limnology, Chinese Academy \\ of Sciences, Nanjing 210008, P. R. China)
}

\begin{abstract}
The predominance of nitrogen fixing cyanobacteria in the eutrophic aquatic systems is related to many environmental factors, such as nutrient forms and concentrations, nitrogen to phosphorus ratio, water temperature and trace metal. The nitrogen fixing cyanobacteria dominated in lakes with the concentration of orthophosphate above $0.01 \mathrm{mg} / \mathrm{L}$, the concentration of dissolved inorganic nitrogen under $0.1 \mathrm{mg} / \mathrm{L}$, furthermore, the lower ratio of nitrogen to phosphorus was suggested to indicate the occurrence of the nitrogen fixing cyanobacteria, but the differentiation mechanism of nitrogen fixing and non-nitrogen fixing cyanobacteria need a deep research. Moreover, cyanobacteria nitrogen fixing rates can be influenced by the light availability, inorganic nitrogen concentrations, heterocyst abundance and the fixed nitrogen determines the contribution to the pools of nitrogen. The nitrogen fixing cyanobacteria is the important contributor to the pools of nitrogen in the ocean systems, but in the eutrophic lakes, its contribution is still in dispute. Thus, this paper reviewed the researches on nitrogen fixing cyanobacteria to attract attention of scientist on its important contribution to the pool of nitrogen in aquatic systems.
\end{abstract}

Keywords: Nitrogen fixing cyanobacteria; rate of nitrogen fixation; nitrogen pool; aquatic ecosystem

伴随人类活动的急剧加强, 由于营养盐过度输人引起的水体富营养化、蓝藻水华频发, 已成为世界范围 内的水环境问题 ${ }^{[1-3]}$. 富营养化水体治理的关键是控制氮、磷等营养盐的输人, 但最近有科学家提出 “减氮不 能控制藻类总量, 反而诱发固氮蓝藻水华” ${ }^{[4-5]}$. 部分丝状蓝藻具有异形胞 (heterocyst), 借助胞内的固氮酶将 大气中游离态的分子氮还原成具有生物可利用性的氮素化合物 ${ }^{[6]}$. 有研究发现在波罗的海, 随着蓝藻固氮

* 湖泊与环境国家重点实验室开放基金项目 (2012SKL006)、河口海岸学国家重点实验室开放基金项目 ( SKLECKF201310) 和国家自然科学基金项目 (41201076,31270507) 联合资助. 2013-01-14 收稿; 2013-08-12 收修改 稿. 叶琳琳 (1981 ), 女, 博士,讲师; E-mail:yelinlin8164@163.com.

** 通信作者;E-mail:fxkong@ niglas. ac. cn. 
速率的增加, 水体中再生的铵态氮浓度显著升高, 这种生态系统内部营养盐的反馈作用可能会加剧蓝藻水 华发生的频率与规模 ${ }^{[7-8]}$.

国外学者很早就对固氮蓝藻进行了大量调查研究, 涉及不同水生生态系统中固氮蓝藻类型 ${ }^{[9-10]}$ 、影响固 氮蓝藻分布和固氮作用的生物及非生物因素、蓝藻固氮对水体中新生氮的贡献作用等 ${ }^{[11-14]}$. 国内关于固氮 蓝藻的研究最早可以追溯到 1959 年黎尚豪等 ${ }^{[15]}$ 综述了从稻田生态系统中分离得到的蓝藻的固氮作用. 随 后的研究开始关注异形胞的结构与功能、影响异形胞生长的环境因子、不同固氮蓝藻固氮酶活性之间的差 异以及海洋蓝藻固氮基因的检测方法等 ${ }^{[6,16-17]}$. 曹秀云等 ${ }^{[18]}$ 逐月分析了 2009-2010 年巢湖固氮蓝藻的分布 特征及其营养盐利用策略. 但到目前为止, 关于水生生态系统中固氮蓝藻生长机理、固氮作用程度的研究还 很缺乏. 有研究发现在加利福尼亚 Iron Gate 和 Copco 水库, 微囊藻水华形成时间滞后于束丝藻水华 ${ }^{[19]}$, 暗示 微囊藻生长的部分氮源可能来自束丝藻的固氮作用 ${ }^{[20]}$. 近年来, 我国太湖、滇池、巢湖蓝藻水华频发, 也出现 固氮和非固氮蓝藻的演替过程: 首先是固氮蓝藻如鱼腥藻、束丝藻在春季形成水华, 随后是没有固氮能力的 微囊藻在夏季形成水华 ${ }^{[4,21-22]}$. 有研究表明在太湖和巢湖, 蓝藻夏季生长过程中受到氮素的限制作用 ${ }^{[23-24]}$, 那么氮限制是不是引起固氮和非固氮蓝藻演替的重要驱动因子? 固氮蓝藻释放的氮源是否会促进非固氮 蓝藻的生长甚至水华形成? 这些问题的回答对于深人研究水体氮素循环机理和蓝藻水华治理具有重要参 考价值. 因此, 本文从固氮与非固氮蓝藻分异的驱动机制、影响蓝藻固氮速率的主要环境因子以及被固定氮 再释放对水体中氮库的贡献作用 3 个方面,来综述水生生态系统中蓝藻的固氮作用.

\section{1 固氮与非固氮蓝藻分异的驱动机制}

\section{1 氮、磷浓度和氮磷比}

影响固氮蓝藻与非固氮蓝藻分异的驱动因素很多, 如营养盐浓度及形态、氮磷比、水温、微量元素 等 ${ }^{[25-29]}$. 近年来, 以色列 Kinneret 湖夏季水体氮限制导致固氮蓝藻念珠藻成为优势种 ${ }^{[29]}$. 一般认为, 湖泊中 正磷酸盐 $(\mathrm{SRP})$ 浓度 $\geqslant 0.01 \mathrm{mg} / \mathrm{L}$ 、溶解性无机氮浓度 $(\mathrm{DIN}) \leqslant 0.1 \mathrm{mg} / \mathrm{L}$ 时, 固氮蓝藻易生长 ${ }^{[9]}$, 并且低的 氮磷比是表征水体中固氮蓝藻形成的重要参数 ${ }^{[28]}$. 有研究发现, 巢湖固氮鱼腥藻占优势, 其次才是非固氮的 微囊藻, 这可能与巢湖较低的总氮总磷比 (TN/TP) 有关 ${ }^{[30]}$. 在加拿大安大略实验湖区进行全湖营养盐操纵 实验, 施加缺氮肥料或只施加磷肥, 结果发现低的氮磷比诱导了固氮鱼腥藻和束丝藻的大量形成 ${ }^{[5]}$. 在瑞典 富营养化湖泊 Limmaren 湖进行围隔实验, 也得到相同结论, 低的氮磷比会引起固氮蓝藻占优势, 在没有添加 氮的实验处理中, 固氮蓝藻生物量所占比例达到 $50 \%{ }^{[31]}$.

以上研究结果表明, 低的氮磷比会诱导固氮蓝藻形成. 但也有研究认为, TN/TP 不能用来指示盐湖生态 系统中固氮蓝藻的出现 ${ }^{[32]}$. 此外, 到目前为止, 对引起水生生态系统中固氮蓝藻占优势的氮磷比的形态及阈 值还存在争议. Howarth 等 ${ }^{[26]}$ 认为固氮蓝藻出现时, 水体中氮磷比 $\leqslant$ Redfield 质量比值 7. Smith 等 ${ }^{[9]}$ 认为 $\mathrm{TN} / \mathrm{TP}$ 质量比 $\leqslant 22$ 时, 固氮蓝藻占优势. 而在欧洲浅水湖泊 Peipsi 湖的研究发现, 固氮蓝藻生物量所占比例 最高时, TN/TP 和 DIN/SRP 质量比都低于 $20^{[33]}$. 溶解性无机氮和正磷酸盐是蓝藻在生长过程中优先利用的 氮、磷形态, DIN/SRP 能更直观地表征氮、磷在水体中的生物有效性及蓝藻对其在生长过程中的吸收利用, 但是这一指标在关于固氮蓝藻的研究过程中往往被忽略. 因此, 通过 TN/TP 和 DIN/SRP 两种氮磷形态比来 表征固氮蓝藻的形成更加科学和严谨. 此外, 引起固氮蓝藻与非固氮蓝藻分异的氮磷比阈值还需要结合研 究对象所属的水生生态系统类型、氮磷营养盐来源格局和固氮蓝藻类型等多种因素综合分析.

\section{2 水温}

大量研究表明温度升高是蓝藻形成优势的重要原因 ${ }^{[34-35]}$. 对太湖 1992-2002 年的研究数据进行统计 分析, 结果表明微囊藻生物量与水温呈显著正相关 ${ }^{[36]}$. 此外, 有研究发现处于温带的新西兰富营养化 Lower Karori 水库, 当水温高于 $15^{\circ} \mathrm{C}$ 时, 鱼腥藻藻细胞增长速度快; 当水温达到最高 $21.3^{\circ} \mathrm{C}$ 时, 藻细胞数量也达到 最大值 ${ }^{[37]}$, 暗示鱼腥藻水华暴发强度随水温升高而增大. 但也有研究结果与此结论相反, 从日本琵琶湖分离 得到的鱼腥藻在 $35^{\circ} \mathrm{C}$ 时生长速率显著降低 ${ }^{[38]}$. 在中国巢湖出现春季鱼腥藻和束丝藻在夏季被微囊藻取代 的演替模式, 水华鱼腥藻细胞密度与水温呈显著负相关 ${ }^{[25,39]}$. 因此, 固氮蓝藻生长与温度的正相关性不适用 于处在热带与亚热带富营养化程度较高的淡水水生生态系统. 但在海洋生态系统中, 温度升高仍有利于固 
氮蓝藻的形成, 研究发现在印度洋桑给巴尔岛附近, 束毛藻生物量与水温呈显著正相关, 在水温达到 $28^{\circ} \mathrm{C}$ 时, 束毛藻生物量达到最大值 ${ }^{[40]}$. 通过室内控制实验也发现相似规律, 束毛藻 IMS 101 最适生长温度为 $27^{\circ} \mathrm{C}$, 虽然在低温 $17^{\circ} \mathrm{C}$ 下仍能存活, 但没有生长迹象 ${ }^{[41]}$. 此外, 固氮蓝藻不同生态型对温度的变化也存在显 著差异. 从波罗的海、日本琵琶湖和 Yogo 湖分离得到的水华束丝藻能适应低温环境生长 ${ }^{[4243]}$, 而在日本京 都大学一个人工富营养化池塘中研究发现, 当温度低于 $11^{\circ} \mathrm{C}$ 时, 水华束丝藻停止生长 ${ }^{[44]}$. 并且太湖鱼腥藻 也存在适应高温和低温的两种生态型. 因此, 在探讨水温对固氮蓝藻分布的影响机制时, 需要结合固氮蓝藻 种类、水生生态系统类型及其所处的气候区域和室内控制实验结果来进行综合分析.

\section{3 微量元素}

此外, 微量元素的含量及其生物可利用性对固氮蓝藻的形成也具有重要影响 ${ }^{[11,4546]}$. 固氮蓝藻在淡水湖 泊中出现较多, 在河口及海洋水环境中出现较少, 即使这些水生生态系统出现氮限制, 也不利于固氮蓝藻的 生长. 大量研究表明 ${ }^{[26]}$, 铁和钿是固氮酶合成的重要微量元素, 它们在海水中生物可利用性低于淡水水体. 研究发现, 钼在有氧水体里面, 主要以钼酸盐形式存在, 而海水中高浓度的硫酸根会抑制固氮蓝藻对钼酸盐 的吸收利用 ${ }^{[45]}$. Marino 等 ${ }^{[32]}$ 对 13 个盐湖研究发现, $\mathrm{SO}_{4}^{2-} / \mathrm{Mo}$ 可以用来表征锄的生物有效性, 这一比值对固 氮蓝藻的分布具有重要影响. 但 Tuit 等 ${ }^{[47]}$ 持不同观点, 认为硫酸根不会影响束毛藻对钼的吸收利用. 因此, 在今后的研究中, 还应结合固氮蓝藻对钼的吸收利用速率、藻细胞内钼含量来综合分析固氮蓝藻对钼的吸 收利用效率,进而探讨硫酸根是否会对此过程产生抑制作用.

铁是藻类生长的重要微量元素. 有研究发现束毛藻在其特定生长环境一一海洋生态系统中受到铁的限 制作用 ${ }^{[484]}$, 因此其对铁的利用效率要高于其它固氮蓝藻如鱼腥藻. 当外界环境铁含量充足时, 束毛藻可以 增加对铁的吸收并存储在细胞内 ${ }^{[46-47]}$. 有研究发现, 中国南海束毛藻丰度较低, 是由低浓度的铁离子引起 的 ${ }^{[50]}$. $\mathrm{Xu}$ 等 ${ }^{[51]}$ 在东太湖研究发现, 铁是微囊藻生长的限制因子, 但是否对固氮蓝藻生长产生影响, 还未见 报道. 此外, 微量元素低的生物有效性是不是导致河口海岸生态系统不适于固氮蓝藻生长的唯一原因还需 要深人探讨. 有研究表明, 浮游动物的摄食和微量元素的耦合作用是导致这一现象的重要原因 ${ }^{[52]}$. 因此, 在 今后的研究中,还应考虑生物因素对固氮蓝藻形成的影响.

\section{2 影响蓝藻固氮速率的环境因子}

蓝藻固氮速率是表征其固氮作用程度的重要指标, 是准确定量被固定氮的再释放对水体中氮循环贡献 作用的重要参数. 乙炔还原法 (acetylene reduction, AR) 和氮同位素示踪 $\left({ }^{15} \mathrm{~N}\right)$ 被广泛应用于蓝藻固氮速率的 测定 ${ }^{[53-54]}$. 表 1 综述了不同水生生态系统中的蓝藻固氮速率.

表 1 乙炔还原法和氮同位素示踪测定蓝藻固氮速率

Tab. 1 Nitrogen fixing rates of cyanobacteria by acetylene reduction and ${ }^{15} \mathrm{~N}$ isotope tracer

\begin{tabular}{cccccccccc}
\hline & 波罗的海 & 波罗的海 & 南海 & 太平洋 & 大西洋 & 大西洋 & Verevi 湖 & Võrtsjärv 湖 & Erie 湖 \\
\hline $\begin{array}{c}\text { 最大固氮速率/ } \\
(\mathrm{mol} /(\mathrm{L} \cdot \mathrm{h}))\end{array}$ & $3.9 \times 10^{-9}$ & $6.5 \times 10^{-9}$ & $15 \times 10^{-9}$ & $18.2 \times 10^{-9}$ & $49.8 \times 10^{-9}$ & $20 \times 10^{-9}$ & $8.9 \times 10^{-9}$ & $7.7 \times 10^{-9}$ & $5.1 \times 10^{-9}$ \\
测定方法 & ${ }^{15} \mathrm{~N}$ & ${ }^{15} \mathrm{~N}$ & ${ }^{15} \mathrm{~N}$ & ${ }^{15} \mathrm{~N}$ & ${ }^{15} \mathrm{~N}$ & ${ }^{15} \mathrm{~N}$ & $\mathrm{AR}$ & $\mathrm{AR}$ & $\mathrm{AR}$ \\
参考文献 & {$[55]$} & {$[56]$} & {$[57]$} & {$[58]$} & {$[59]$} & {$[60]$} & {$[61]$} & {$[62]$} & {$[11]$} \\
\hline
\end{tabular}

\section{1 光照}

生物固氮需要消耗大量的能量, 每 2 个电子传递就需要消耗 $4 \sim 5$ 个 ATP, 因此光是影响蓝藻固氮 速率的重要环境因子 ${ }^{[63-64]}$. 在维多利亚湖研究发现, 蓝藻固氮速率从近岸 $(0.90 \mu \mathrm{g} /(\mathrm{L} \cdot \mathrm{h}))$ 向远岸区域 $(0.11 \mu \mathrm{g} /(\mathrm{L} \cdot \mathrm{h}))$ 逐渐减少, 湖心出现最低值, 主要是由于近岸区域平均光照强度比远岸区域高 ${ }^{[65]}$. 在宾 夕法尼亚 Sanctuary 湖, 由于光的抑制作用, 鱼腥藻固氮速率随着水深增大而减少 ${ }^{[66]}$. 在澳大利亚 Peel-Harvey 河口也得到相同规律, 节球藻固氮速率随着水深增大而减少 ${ }^{[67]}$. 但通过对野外实验数据进行统计分析, 结果 表明鱼腥藻水华暴发时水下可利用性光强度大, 而束丝藻对光照强度要求不高 ${ }^{[68]}$. 室内模拟实验也发现, 黑 暗条件下, 束丝藻的固氮速率要高于鱼腥藻 ${ }^{[69-70]}$. 此外, 也有研究表明, 在强光照条件下, 节球藻固氮作用受 
到抑制 ${ }^{[71]}$. 因此, 不同蓝藻固氮作用对光的响应机制可能存在差异 ${ }^{[72]}$. 有研究表明, 蓝藻固氮速率对光照的 响应程度分为两种类型: 第一类型蓝藻必须有光照才可以开始固氮作用, 比如柱胞鱼腥藻. 黑暗条件下不能 进行固氮, 可能是因为从生长细胞分化来的异形胞内缺乏光合作用产物, 并且固氮酶的合成被中断. 第二类 型蓝藻在光照和黑暗中都可以固氮, 由于异形胞存储了大量碳水化合物, 因此能维持黑暗条件下的固氮作 用, 但是固氮速率在黑暗条件下比光照条件下要低 ${ }^{[73-74]}$. 有研究发现, 水华束丝藻和泡沫节球藻在黑暗条件 下固氮速率分布是有光照条件下的 $50 \%$ 和 $20 \%{ }^{[75]}$.

\section{2 异形胞丰度}

异形胞是蓝藻中某些丝状体种类所特有的一种能固氮的细胞, 它们是由藻丝细胞中的一些营养细胞转 化而来的. 从研究和测定过固氮能力的蓝藻中发现, 150 多种固氮蓝藻中绝大多数都具有异形胞的分化. 因 此, 异形胞的丰度可以用来表征蓝藻固氮作用程度. 对 Lake 227 研究发现, 柔细束丝藻 (Aphanizomenon gracile) 固氮速率与异形胞数量呈显著正相关 ${ }^{[76]}$. 通过室内控制实验研究发现, 从波罗的海分离出来的水华束丝 藻的固氮速率与异形胞丰度呈正相关, 虽然水华束丝藻异形胞丰度低于泡沫节球藻 (Nodularia spumigena), 但其固氮速率仍高于泡沫节球藻. 结果表明, 这两种固氮蓝藻异形胞固氮能力、固氮酶的活性具有显著差 异 ${ }^{[42]}$. 因此, 异形胞丰度与固氮速率呈正相关的定律并不适用于种间的数据统计分析. 此外, 也有研究发现, 此定律也不适用于短时间尺度 (几小时或几天) 范围内的数据分析 ${ }^{[77]}$. 因此, 在探讨异形胞对蓝藻固氮速率 影响机制的时候,应综合考虑固氮蓝藻异形胞固氮能力的种间差异以及数据获得的时间尺度.

\section{3 溶解性无机氮浓度与形态}

固氮蓝藻吸收利用铵态氮和硝态氮的能量要小于合成固氮酶进行固氮作 用 $^{[78-79]}$, 研究发现海水中溶解 性无机氮浓度高于 $1 \mu \mathrm{mol} / \mathrm{L}$ 时, 固氮速率受到抑制 ${ }^{[80]}$, 因此, 只有当溶解性无机氮源耗竭的时候, 固氮蓝藻 才开始固氮 ${ }^{[81]}$. 在美国佛罗里达州 Okeechobee 湖研究发现, 溶解性无机氮浓度升高, 蓝藻固氮速率受到抑 制 ${ }^{[82]}$. 在美国宾夕法尼亚 Sanctuary 湖, 硝态氮和铵态氮浓度迅速降低导致鱼腥藻固氮速率显著升高 ${ }^{[66]}$. 以 上研究结果表明,铵态氮和硝态氮会抑制固氮酶的合成,对蓝藻固氮速率产生影响.

但不同类型固氮蓝藻, 其固氮速率对两种无机氮的响应可能还存在一定差异. 有研究表明, 铵态氮对固 氮酶的抑制作用比硝态氮强 ${ }^{[83]}$. 研究发现, 在黑暗条件下, $10 \mu \mathrm{mol} / \mathrm{L}$ 的铵态氮对固氮蓝藻 Crocosphaera watsonii ( WH8501 和 WH0003) 固氮速率的抑制率分别为 36\% 和 $83 \%{ }^{[84]}$, 而同等浓度的硝态氮对固氮速率并没 有显著影响, 可能原因是 Crocosphaera watsonii 在黑暗条件下, 吸收利用硝态氮获得能量, 完成固氮酶的合 成, 从而进行固氮作用. 但以束毛藻为研究对象, 在黑暗条件下, 相同浓度的硝态氮对其固氮速率的抑制率 为 $50 \%{ }^{[81]}$. 以上研究结果表明, 某些固氮蓝藻在吸收利用溶解性无机氮的同时仍然能进行固氮作用, 并保 持较高的固氮速率. 最近一项研究表明, 高浓度的正磷酸盐能增加固氮蓝藻丰度, 因此缓解了硝态氮对蓝藻 固氮速率的抑制作用, 研究发现固氮蓝藻在 $5 \mu \mathrm{mol} / \mathrm{L}$ 的硝态氮和 $1.0 \mu \mathrm{mol} / \mathrm{L}$ 的正磷酸盐培养体系中的固 氮速率与没有添加硝态氮、正磷酸盐浓度为 $0.5 \mu \mathrm{mol} / \mathrm{L}$ 系统中的固氮速率没有显著差异 ${ }^{[85]}$.

在上一部分, 我们综述了异形胞丰度对蓝藻固氮速率的影响. 有研究发现, 无机氮浓度与形态对异形胞 的形成具有抑制作用, 以铵态氮作为氮源, 固氮蓝藻异形胞丰度最低 ${ }^{[86]}$. 因此, 在探讨无机氮对蓝藻固氮速 率的影响机制的时候, 还应考虑无机氮源对异形胞形成的作用, 从而引起的对蓝藻固氮速率的间接影响.

\section{4 有机物}

有研究表明, 在波罗的海, 固氮蓝藻水华形成过程中受到铁限制, 添加溶解性有机物可以络合大量铁离 子, 促进固氮蓝藻形成 ${ }^{[87]}$, 但作者并没有深人探讨添加有机物是否会促进蓝藻固氮速率. 在大西洋近岸海 域, 添加糖类如葡萄糖、麦芽糖等能诱导固氮作用和增加固氮速率 ${ }^{[48]}$. Paulsen 等 $^{[88]}$ 的研究也发现相同的规 律: 在沙克尔福德海滩添加葡萄糖和甘露醇能提高蓝藻固氮速率. 可能原因是固氮蓝藻利用有机物过程中 消耗氧气, 导致水体微环境出现厌氧, 因此有利于固氮作用的加强 ${ }^{[48]}$.

\section{3 被固定氮对水体中氮库的贡献作用}

蓝藻固氮是海洋生态系统中 “新” 氮素的重要来源 ${ }^{[12,89]}$. 固氮蓝藻形成初期固氮速率高, 形成的氮素化 合物可以从处于生长阶段的藻细胞中释放出来, 而在生长后期, 虽然固氮速率较低, 但藻细胞大量死亡并裂 
解, 也会释放大量氮源. 固氮蓝藻新固定的氮多以铵态氮或溶解性有机氮的形式被释放, 研究发现, 被束毛 藻释放的氮中有 $50 \%$ 是溶解性有机氮 ${ }^{[13]}$, 通过细菌分解转化成溶解性无机氮, 可被其它生物再吸收利用. 在大西洋研究发现, 硅藻的生长导致水体中溶解性无机氮耗竭, 为固氮蓝藻束毛藻的生长提供了适宜的条 件, 而被束毛藻固定氮的再释放又为鞭毛藻的生长补充了氮源, 因此, 浮游植物出现硅藻一束毛藻一鞭毛藻的 演替规律 ${ }^{[90]}$. 以上研究结果表明, 固氮蓝藻氮释放是水体中氮素循环的重要环节, 但如何准确定量再释放的 氮通量一直是相关研究领域中的难点. Mulholland 等 ${ }^{[91-93]}$ 通过室内模拟和野外调查研究发现, 乙炔还原法和 氮同位素示踪所测得的速率分别代表总固氮速率和净固氮速率, 两者之差可以用来表征被固定新氮的释放 通量. 运用这种方法在墨西哥湾的研究发现, 束毛藻能释放出被固定氮的 $52 \%$, 为非固氮藻类 (腰鞭毛藻) 生 长提供氮源 ${ }^{[92]}$.

但是在湖泊生态系统中, 关于蓝藻固氮对水体中氮库的贡献作用还存在争议 ${ }^{[29]}$. 在委内瑞拉巴伦西亚

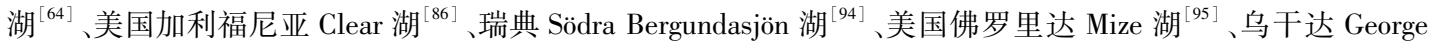
湖 ${ }^{[96]}$ 、加拿大曼尼托巴 885 湖 $^{[97]}$ 等湖泊中发现, 蓝藻固氮对湖泊生态系统中氮的贡献量很大, 其中在 Kinneret 湖, 束丝藻水华暴发期间, 对水体中氮的贡献量高达 $700 \mathrm{t}^{[14]}$. 有研究发现, 在美国威斯康辛州 Mendota 湖, 束丝藻和微囊藻交替出现, 蓝藻固氮速率达到最大值后, 微囊藻毒素显著升高, 结果表明固氮蓝藻的氮 释放有利于维持产毒微囊藻水华的生长 ${ }^{[98]}$. 但也有研究认为, 被固定氮的释放对水体中氮库的贡献作用很 小 ${ }^{[99]}$. 表 2 归纳了不同营养级别的湖泊中蓝藻固定的氮对水体中氮库的贡献作用. 结果发现, 水体的营养状 态与固氮蓝藻对氮库的贡献程度并没有显著相关性. 表 2 中固氮蓝藻对水体的贡献是通过结合固氮速率和 固氮蓝藻丰度来估算的, 由于研究对象中固氮速率的时空异质性, 这种方法不一定能准确还原水体中的真 实情况. 近来有研究发现, 由于对束毛藻生物量估计不足 ${ }^{[104]}$, 固氮蓝藻对海洋生态系统的贡献作用要高于 目前研究所获得的结果 ${ }^{[105]}$, 而与水体中发生的反硝化作用基本持平 ${ }^{[106]}$. 因此, 在目前的研究, 可通过定量 固氮蓝藻水华期间水体中氮的输人输出变化通量准确估算固氮蓝藻对水体中氮库的贡献作用.

表 2 不同水体中蓝藻固定的氮对水体中氮库的贡献

Tab. 2 The percentage of total nitrogen input to the system contributed by nitrogen

fixation in various types of water

\begin{tabular}{lcccc}
\hline 水体 & 营养状态 & 贡献比例/\% & 测定方法 & 参考文献 \\
\hline Erken 湖(瑞典) & 富营养 & 82 & AR & {$[11]$} \\
Pyramid 湖(美国) & 贫营养(咸水) & 81 & AR & {$[11]$} \\
Tohopekaliga 湖(美国) & 富营养 & 44 & AR & {$[100]$} \\
Clear 湖(美国) & 富营养 & 43 & AR & {$[86]$} \\
Waci 水库(美国) & 富营养 & 4.9 & AR & {$[101]$} \\
Võrtsjärv 湖(爱沙尼亚) & 富营养 & 2.34 & AR & {$[62]$} \\
Verevi 湖(爱沙尼亚) & 超富营养 & $<1$ & AR & {$[61]$} \\
Sammamish 湖和 Washington 湖(美国) & 中富营养 & 1 & - & {$[102]$} \\
Chester Morse 湖和 Findley 湖(美国) & 贫营养 & 1 & - & {$[102]$} \\
Washington 湖(美国) & 中富营养 & 0.29 & AR & {$[11]$} \\
Superior 湖、Huron 湖、Michigan 湖(美国) & 贫营养 & 0.02 & AR & {$[11]$} \\
Mono 湖(美国) & 贫营养(咸水) & 0 & 15 N & {$[103]$} \\
\hline
\end{tabular}

\section{4 总结和展望}

蓝藻是富营养化水体中主要的优势种. 但是, 目前国内就富营养化水生生态系统中蓝藻水华的形成机 制与蓝藻时空分布特征等方面开展了大量的研究工作 ${ }^{[25,35]}$, 而对固氮蓝藻的关注远远不够. 引起固氮蓝藻 占优势的主要环境因子有哪些? 蓝藻的固氮速率是多少? 环境因素包括生物 (浮游动物摄食) 和非生物因 素对蓝藻固氮速率的影响如何? 被固定氮的再释放对水体氮库的贡献是多少? 这些方面的研究鲜见报道. 对于蓝藻水华频发、出现固氮和非固氮蓝藻演替的巢湖和太湖, 探索固氮蓝藻氮释放对于微囊藻水华, 尤其 
是产毒微囊藻的形成是否具有重要影响, 显得尤为重要. 因此, 以固氮蓝藻为研究对象, 揭示固氮蓝藻的分 布规律, 明确固氮与非固氮蓝藻分异的主要环境因子阈值, 探索被固定氮的归趋及其对水生生态系统中氮 循环的贡献对加强水体氮循环研究以及蓝藻水华治理具有重要意义.

\section{5 参考文献}

[ 1 ] Dokulil M, Teubner K. Cyanobacterial dominance in lakes. Hydrobiologia, 2000, 438(1/2/3):1-12.

[ 2 ] Paerl HW. Controlling eutrophication along the freshwater-marine continuum: dual nutrient $(\mathrm{N}$ and $\mathrm{P})$ reductions are essential. Estuaries and Coasts, 2009, 32(4) : 593-601.

[3] 盛 虎,郭怀成,刘 慧等. 滇池外海蓝藻水华爆发反演及规律探讨. 生态学报, 2012,32(1):56-63.

[ 4 ] 王海军,王洪铸. 富营养化治理应该放宽控氮、集中控磷. 自然科学进展,2009,19(6):599-604.

[ 5 ] Schindler DW, Hecky RE, Findlay DL et al. Eutrophication of lakes cannot be controlled by reducing nitrogen input: Results of 37-year whole-ecosystem experiment. Proceedings of the National Academy of Sciences of the United States of America, 2008, $\mathbf{1 0 5}(32): 11254-11258$.

[6] 周云龙. 异形胞与蓝藻的固氮. 生物学通报, 1994,29(11):5-6.

[ 7 ] Ohlendieck U, Gundersen K, Meyerhofer M et al. The significance of nitrogen fixation to new production during early summer in the Baltic Sea. Biogeosciences, 2007, 4(1):63-73.

[ 8 ] Vahtera E, Coonley DJ, Gustafsson BG et al. Internal ecosystem feedbacks enhance nitrogen-fixing cyanobacteria blooms and complicate management in the Baltic Sea. Ambio, 2007, 36(2) :186-194.

[ 9 ] Smith VH, Bierman VJ, Jones BL et al. Historical trends in the Lake Okeechobee ecosystem IV. Nitrogen : phosphorus ratios, cyanobacterial dominance, and nitrogen fixation potential. Archiv für Hydrobiologie, 1995, 107(1) : $71-88$.

[10] Kahru M, Leppanen JM, Rud O et al. Cyanobacteria blooms in the Gulf of Finland triggered by saltwater inflow into the Baltic Sea. Marine Ecology Progress Series, 2000, 207 : 13-18.

[11] Howarth RW, Marino R, Lane J et al. Nitrogen fixation in freshwater, estuarine, and marine ecosystems. 1. Rates and importance. Limnology and Oceanography, 1988, 33(4part2) : 669-687.

[12] Karl D, Letelier R, Tupas L et al. The role of nitrogen fixation in biogeochemical cycling in the subtropical North Pacific Ocean. Nature, 1997, 388(7) : 533-538.

[13] Glibert PM, Bronk DA. Release of dissolved organic nitrogen by marine diazotrophic cyanobacteria, Trichodesmium spp. Applied and Environmental Microbiology, 1994, 60(11):3996-4000.

[14] Gophen M, Smith VH, Nishri A et al. Nitrogen deficiency, phosphorus sufficiency, and the invasion of Lake Kinneret, Israel, by the $\mathrm{N}_{2}$-fixing cyanobacterium Aphanizomenon ovalisporum. Aquatic Sciences, 1999, 61 (4) :293-306.

[15] 黎尚豪,叶清泉,刘富瑞等. 我国的几种蓝藻的固氮作用. 水生生物学集刊, 1959,4:429-439.

[16] 中国科学院水生生物研究所第五室生化、遗传组. 几种固氮蓝藻的固氮酶活性及其某些特性. 水生生物学集刊, 1980,7 ( 1 ) :57-60.

[17] 丁昌玲,孙 军, 顾海峰等. 海洋蓝藻固氮基因. 海洋科学,2008,32(7):75-80.

[18］曹秀云, 宋春雷, 周易勇. 巢湖固氮蓝藻的分布特征及其营养盐利用策略. 见: 中国藻类学会第八次会员代表大会 暨第十六次学术讨论会论文摘要集,2011.

[19] Kann J, Asarian E. Nutrient budgets and phytoplankton trends in Iron Gate and Copco Reservoirs, California, May 2005May 2006. Final Technical Report to the State Water Resources Control Board, Sacramento, California, 2007.

[20] Moisander PH, Ochiai M, Lincoff A. Nutrient limitation of Microcystis aeruginosa in northern California Klamath River reservoirs. Harmful Algae, 2009, 8(6):889-897.

[21] 李 原, 张 梅,王若南. 滇池的水华蓝藻的时空变化. 云南大学学报: 自然科学版,2005,27(3):272-276.

[22] 吕兴菊,朱 江, 孟 良. 洱海水华蓝藻多样性初步研究. 环境科学导刊,2010,29(3):32-35.

[23] Xu H, Paerl HW, Qin BQ et al. Nitrogen and phosphorus inputs control phytoplankton growth in eutrophic Lake Taihu, China. Limnology and Oceanography, 2010, 55(1): 420-432.

[24] 王书航,姜 霞, 金相灿. 巢湖水环境因子的时空变化及对水华发生的影响. 湖泊科学,2011,23(6):873-880.

[25] 贾晓会, 施定基, 史绵红等. 巢湖蓝藻水华形成原因探索及 “优势种光合假说”. 生态学报, 2011, 31 ( 11): 2968-2977. 
[26] Howarth RW, Marino R, Cole JJ. Nitrogen fixation in freshwater, estuarine, and marine ecosystems. 2. Biogeochemical controls. Limnology and Oceanography, 1988, 33(4part2) : 688-701.

[27] Niemi A. Blue-green algal blooms and N:P ratio in the Baltic Sea. Acta Botanica Fennica, 1979, 110 : $57-61$.

[28] Havens KE, James RT, East T et al. N:P ratios, light limitation, and cyanobacterial dominance in a subtropical lake impacted by non-point source nutrient pollution. Environmental Pollution, 2003, 122 (3) :379-390.

[29] Hadas O, Pinkas R, Malinsky-Rushansky N et al. Appearance and establishment of diazotrophic cyanobacteria in Lake Kinneret, Israel. Freshwater Biology, 2012, 57(6):1214-1227.

[30] 谢 平. 翻阅巢湖的历史一一蓝藻、富营养化及地质演化. 北京:科学出版社, 2009:105.

[31] Vrede T, Ballantyne A, Mille-Lindblom C et al. Effects of N:P loading ratios on phytoplankton community composition, primary production and N fixation in a eutrophic lake. Freshwater Biology, 2009, 54(2) : 331-344.

[32] Marino R, Howarth RW. Molybdenum and sulfate as controls on the abundance of nitrogen-fixing cyanobacteria in saline lakes in Alberta. Limnology and Oceanography, 1990, 35(2):245-259.

[33] Toges T, LaugasteR, Noges P et al. Critical N:P ratio for cyanobacterial and $\mathrm{N}_{2}$-fixing species in the large shallow temperature lakes Peipsi and Võrtsjärv, North-East Europe. Hydrobiologia, 2008, 599(1) :77-86.

[34] Parel HW, Fulton RS, Moisander PH et al. Harmful freshwater algal blooms with an emphasis on cyanobacteria. The Scientific World Journal, 2001, 1 :76-113.

[35] 孔繁翔,高 光. 大型浅水富营养化湖泊中蓝藻水华形成机理的思考. 生态学报,2005,25(3):589-595.

[36] Liu X, Lu X, Chen Y. The effects of temperature and nutrient ratios on Microcystis blooms in Lake Taihu, China: An 11year investigation. Harmful Algae, 2011, 10:337-343.

[37] Wood SA, Prentice MJ, Smith K et al. Low dissolved inorganic nitrogen and increased heterocyte frequency : precursors to Anabaena planktonica blooms in a temperate, eutrophic reservoir. Journal of Plankton Research, 2010,32 ( 9 ) : 1315-1325.

[38 ] Nalewajko C, Murphy TP. Effects of temperature, and availability of nitrogen and phosphours on the abundance of Anabae$n a$ and Microcystis in Lake Biwa, Japan: an experimental approach. Limnology, 2001, 4:45-48.

[39] 蔡元锋. 太湖、巢湖蓝藻组成演替及驱动因子的比较研究 [ 学位论文]. 南京: 中国科学院南京地理与湖泊研究 所, 2012 .

[40] Lugomela C, Lyimo TJ, Bryceson I et al. Trichodesmium in coastal waters of Tanzania: diversity, seasonality, nitrogen and carbon fixation. Hydrobiologia, 2002, $477: 1-13$.

[41] Breitbarth E, Oschlies A, LaRoche J. Physiological constraints on the global distribution of Trichodesmium-effect of temperature on diazotrophy. Biogosciences, 2007, 4:53-61.

[42] Lehtimaki J, Moisander P, Sivonen K et al. Growth, nitrogen fixation, and nodularin production by two baltic sea cyanobacteria. Applied and Environmental Microbiology, 1997, 63(5) :1647-1656.

[43] Tsujimura S, Ishikawa K, Tsukada H. Effects of temperature on growth of the cyanobacterium Aphanizomenon flos-aquae in Lake Biwa and Lake Yogo. Phycological Research, 2001, 49:275-280.

[44] Yamamoto Y, Nakahara H. The formation and degradation of cyanobacterium Aphanizomenon flos-aquae blooms: the importance of $\mathrm{pH}$, water temperature, and day length. Limnology, 2005, 6:1-6.

[45] Marino R, Howarth RW, Chan F et al. Sulfate inhibition of molybdenum-dependent nitrogen fixation by planktonic cyanobacteria under seawater conditions: a non-reversible effect. Hydrobiologia, 2003 , 500:277-293.

[46] Berman-Frank I, Quigg A, Finkel ZV et al. Nitrogen-fixation strategies and Fe requirments in cyanobacteria. Limnology and Oceanography, 2007, $52(5)$ : 2260-2269.

[47] Tuit C, Waterbury J, Ravizza G. Diel variation of molybdenum and iron in marine diazotrophic cyanobaceria. Limnology and Oceanography, 2004, 49 (4):978-990.

[48] Paerl HW, Crocker KM, Prufert LE. Limitation of $\mathrm{N}_{2}$ fixation in coastal marine waters: Relative importance of molybdenum, iron, phosphorus, and organic matter availability. Limnology and Oceanography, 1987, 32(3) :525-536.

[49] Rueter JG. Iron stimulation of photosynthesis and nitrogen fixation in Anabaena 7120 and Trichodesmium (Cyanophyceae). Journal of Phycology, 1988, 24 :249-254.

[50] Wu J, Chung SW, Wen LS et al. Dissolved inorganic phosphorus, dissolved iron, and Trichodesmium in the oligotrophic South China Sea. Global Biogeochemical Cycles, 2003, 17 (1) : 8-1-8-10. 
[51] Xu H, Zhu G, Qin B et al. Growth response of Microcystis spp. to iron enrichment in different regions of Lake Taihu, China. Hydrobiologia, 2013 , $700: 187-202$.

[52] Howarth RW, Chan F, Marino R. Do top-down and bottom-up controls interact to exclude nitrogen-fixing cyanobacteria from the plankton of estuaries? An exploration with a stimulation model. Biogeochemistry, 1999, 46:203-231.

[53] Montoya JP, Voss M, Kahler P et al. A simple, high-precision, high sensitivity tracer assay for $\mathrm{N}_{2}$ fixation. Applied and Environmental Microbiology, 1996, 62 (3) :986-993.

[54] Scott JT, Stanley JK, Doyle RD et al. River-reservoir transition zones are nitrogen fixation hot spots regardless of ecosystem trophic state. Hydrobiologia, 2009, 625(1):61-68.

[55] Ohlendieck U, Stuhr A, Siegmund H. Nitrogen fixation by diazotrophic cyanobacteria in the Baltic Sea and transfer of the newly fixed nitrogen to picoplankton organisms. Journal of Marine Systems, 2000, 25(3/4) :213-219.

[56] Wasmund N, Voss M, Lochte K. Evidence of nitrogen fixation by non-heterocystous cyanobacteria in the Baltic Sea and recalculation of a budget of nitrogen fixation. Marine Ecology Progress Series, 2001, 214:1-14.

[57] Grobe J. Effects of the Mekong River on abundance and $\mathrm{N}_{2}$-fixation rates of cyanobacteria in the South China Sea. Universität Rostock, 2007.

[58] Bonnet S, Biegala IS, Dutrieux P et al. Nitrogen fixation in the western equatorial Pacific: Rates, diazotrophic cyanobacterial size class distribution, and biogeochemical significance. Global Biogeochemical Cycles, 2009 , 23 : GB3012.

[59] Mulholland MR, Bernhardt PW, Blanco-garcia JL et al. Rates of dinitrogen fixation and the abundance of diazotrophs in North American coastal waters between Cape Hatteras and Georges Bank. Limnology and Oceanography, 2012,57 (4) : 1067-1083.

[60] Rees AP, Gilbert JA, Kelly-Gerreyn BA. Nitrogen fixation in the western English Chanel( NE Atlantic Ocean). Marine Ecology Progress Series, 2009, 374:7-12.

[61] Tonno I, Ott K, Noges T. Nitrogen dynamics in steeply stratified, temperate, Lake Verevi, Estonia. Hydrobiologia, $2005, \mathbf{5 4 7}(1): 63-71$.

[62] Tonno I, Noges T. Nitrogen fixation in a large shallow lakes: rates and initiation conditions. Hydrobiologia, 2003,490 $(1 / 2 / 3): 23-30$.

[63] Brock TD, Madigan MT, Matinko JM et al. Biology of microorganisms. New York:Prentice-Hall Inc. , 1994.

[64] Levine SN, Lewis WM. A numerical model of nitrogen fixation and application to lake Valencia, Venezuela. Freshwater Biology, 1987, 17(2): 265-274.

[65] Mugidder R, Hecky RE, Hendzel L et al. Pelagic nitrogen fixation in Lake Victoria(East Africa). J Great Lakes Res, 2003, 29 (supplement 2 ) :76-88.

[66] Dugdale VA, Dugdale RC. Nitrogen metabolism in lakes II. Role of nitrogen fixation in Sanctuary Lake, Pennsylvania. Limnology and Oceanography, 1962, 7 (2):170-177.

[67] Huber AL. Nitrogen fixation by Nodularia spumigena Mertens(Cyanobacteriaceae). 1: Field studies and the contribution of blooms to the nitrogen budget of the Peel-Harvey Estuary, Western Australia. Hydrobiologia, 1986, 131(3) :193-203.

[68] Schreurs H. Cyanobacterial dominance. Relations to eutrophication and lake morphology. Amsterdam: University of Amsterdam, 1992.

[69] Bradburn MJ, Lewis JRWM, Mccutchan JRJH. Comparative adaptations of Aphanizomenon and Anabaena for nitrogen fixation under weak irradiance. Freshwater Biology, 2012, 57 (5) :1042-1049.

[70 ] De Nobel WT( PIM), Matthijs HCP, Von Elert E et al. Comparison of the light-limited growth of the nitrogen-fixing cyanobacteria Anabaena and Aphanizomenon. New Phytologist, 1998, 138(4) : 579-587.

[71] Stal L, Walsby A. Photosynthesis and nitrogen fixation in a cyanobacterial bloom in the Baltic Sea. European Journal of Phycology, 2000, 35(2):97-108.

[72] Millineaux PM, Gallon JR, Chaplin AE. Acetylene reduction( nitrogen fixation) by cyanobacteria grown under alternating light-dark cycles. FEMS Microbiology Letters, 1981, 10 (3) :245-247.

[73] Khamees HS, Gallon JR, Chaplin AE. The pattern of acetylene reduction by cyanobacteria grown under alternating light and darkness. British Phycological Journal, 1987, 22 (1) :55-60.

[74] Fay P. Factors influencing dark nitrogen fixation in blue-green algae. Applied and Environmental Microbiology, 1976,31 (3) : 376-379. 
[75] Evans AM, Gallon JR, Jones A et al. Nitrogen fixation by Baltic cyanobacteria is adapted to the prevailing photon flux density. New Phytologist, 2000, 147 (2) :285-297.

[76] Findlay DL, Hecky RE, Hendzel LL et al. Relationship between $\mathrm{N}_{2}$-fixation and heterocyst abundance and its relationship to the nitrogen budget of Lake 227. Canadian Journal of Fisheries and Aquatic Sciences, 1994, 51 :2254-2266.

[77] Laamanen M, Kuosa H. Annual variability of biomass and heterocysts of the $\mathrm{N}_{2}$-fixing cyanobacterium Aphanizomenon flosaquae in the Baltic Sea with reference to Anabaena spp. and Nodularia spumigena. Boreal Environment Research, 2005 , 10 : 19-30.

[78] Mulholland MR, Ohki K, Capone DG. Nitrogen utilization and metabolism relative to patterns of $\mathrm{N}_{2}$ fixation in cultures of Trichodesmium NIBB1067. Journal of Phycology, 1999, 35(5) :977-988.

[79] Sprober P, Shafik HM, Presing M et al. Nitrogen uptake and fixation in the cyanobacterium Cylindrospermopsis raciborskii under different nitrogen conditions. Hydrobiologia, 2003, 506-509(1/2/3):169-174.

[80] Knapp AN. The sensitivity of marine $\mathrm{N}_{2}$ fixation to dissolved inorganic nitrogen. Frontiers in Microbiology, $2012,3: 374$.

[81] Holl CM, Montoya JP. Interactions between nitrate uptake and nitrogen fixation in continuous cultures of the marine diazotroph Trichodesmium (Cyanobacteria). Journal of Phycology, 2005, 41 (6) :1178-1183.

[82] Phlips EJ, Cichra M, Haves K et al. Relationships between phytoplankton dynamics and the availability of light and nutrients in a shallow sub-trophic lake. Journal of Plankton Research, 1997, 19(3):319-342.

[83] Ogawa RE, Carr JF. The influence of nitrogen on heterocyst production in blue-green algae. Limnology and Oceanography, $1969, \mathbf{1 4}(3): 342-351$.

[84] Dekaezemacker J, Bonnet S. Sensitivity of $\mathrm{N}_{2}$ fixation to combined nitrogen forms $\left(\mathrm{NO}_{3}^{-}\right.$and $\left.\mathrm{NH}_{4}^{+}\right)$in two strains of the marine diazotroph Crocosphaera watsonii( Cyanobacteria). Marine Ecology Progress Series, 2011, 438:33-46.

[85] Knapp AN, Dekaezemacker J, Bonnet S et al. Sensitivity of Trichodesmium and Crocosphaera abundance and $\mathrm{N}_{2}$ fixation rates to varying $\mathrm{NO}_{3}^{-}$and $\mathrm{PO}_{4}^{3-}$ concentrations in bacth cultures. Aquatic Microbial Ecology, 2012, 66:223-236.

[86] Horne AJ, Goldman CR. Nitrogen fixation in Clear Lake, California. I. Seasonal variation and the role of heterocysts. Limnology and Oceanography, 1972, 17(5) : 693-703.

[87] Stolte W, Balode M, Carlsson P et al. Stimulation of nitrogen-fixing cyanobacteria in a Baltic Sea plankton community by land-derived organic matter or iron additon. Marine Ecology Progress Series, 2006, 327 :71-82.

[88] Paulsen DM, Paerl HW, Bishop PE. Evidence that molybdenum-dependent nitrogen fixation is not limited by high sulfate concentrations in marine environments. Limnology and Oceanography, 1991, 36(7) :1325-1334.

[89] 董俊德, 王汉奎, 张 偲等. 海洋固氮生物多样性及其对海洋生产力的氮、碳贡献. 生态学报, 2002,22(10): $1741-1749$.

[90] Hood RR, Cole VJ, Capone DG. Modeling the distribution of Trichodesmium and nitrogen fixation in the Atlantic Ocean. Journal of Geophysical Research, 2004, 109: C06006.

[91] Mulholland MR, Bronk DA, Capone DG. Dinitrogen fixation and release of ammonium and dissolved organic nitrogen by Trichodesmium IMS101. Aquatic Microbial Ecology, 2004, 37 (1) :85-94.

[92] Mulholland MR, Bernhardt PW, Heil CA et al. Nitrogen fixation and release of fixed nitrogen by Trichodesmium spp. in the Gulf of Mexico. Limnology and Oceanography, 2006, 51(4) :1762-1776.

[93] Mulholland MR, Bernhardt PW. The effect of growth rate, phosphorus concentration, and temperature on $\mathrm{N}_{2}$ fixation, carbon fixation, and nitrogen release in continuous cultures of Trichodesmium IMS 101. Limnology and Oceanography, 2005, $\mathbf{5 0}(3): 839-849$.

[94] Leonardson L, Bengtsson L. Effects of sewage diversion in Lake Södra Bergundasjön. II . Phytoplankton changes and the role of nitrogen fixation. Verhandlungen der Internationale Vereinigung für Limnologie, 1978, 20 :2701-2707.

[95] Keirn MA, Brezonik PL. Nitrogen fixation by bacteria in Lake Mize, Florida, and in some lacustrine sediments. Limnology and Oceanography, 1971, 16(5):720-731.

[96] Horne AJ, Viner AB. Nitrogen fixation and its significance in tropical Lake Geroge, Uganda. Nature, 1971, 232: $417-418$.

[97] Brownlee BG, Murphy TP. Nitrogen fixation and phosphorus turnover in a hypertrophic prarie lake. Canadian Journal of Fisheries and Aquatic Sciences, 1983, 40(11) :1853-1860. 
[ 98 ] Beversdorf LJ, Miller TR, McMahon KD. The role of nitrogen fixation in cyanobacterial bloom toxicity in a temperate, eutrophic lake. PLoS ONE, 2013, 8(2): e56103.

[ 99 ] Ferber LR, Levine SN, Linni A et al. Do cyanobacteria dominate in eutrophic lakes because they fix atmospheric nitrogen? Freshwater Biology, 2004, 49 (6) :690-708.

[100] Dierberg FE, Scheinkman MM. Contribution from nitrogen fixation(acetylene reduction) to the nitrogen budget of Lake Tohopekaliga(Florida). Hydrobiologia, 1987, 154 (1):61-73.

[101] Scott JT, Doyle RD, Prochnow SJ et al. Are watershed and lacustrine conditions on planktonic $\mathrm{N}_{2}$ fixation hierarchically structured? Ecological Applications, 2008, 18 (3) :805-819.

[102] Tison DL, Palmer FE, Staley JT. Nitrogen fixation in lakes of the lake Washington drainage basin. Water Research, $1977, \mathbf{1 1}(9): 843-847$.

[103] Steward GF, Zehr JP, Jellison R et al. Vertical distribution of nitrogen-fixing phylotypes in meromictic, hyper-saline lake. Microbiol Ecology, 2004, 47(1) : 30-40.

[104] Davis CS, McGillicuddy DJ. Transatlantic abundance of the $\mathrm{N}_{2}$-fixing colonial cyanobacterium Trichodesmium. Science, $2006,312: 1517-1520$.

[105] Codispoti LA. An oceanic fixed nirogen sink exceeding $400 \mathrm{Tg} \mathrm{N} \mathrm{a}^{-1}$ vs the concept of homeostasis in the fixed-nitrogen inventory. Biogeosciences, 2007, 4:233-253.

[106] Deutsch C, Sarmiento JL, Sigman DM et al. Spatial coupling of nitrogen inputs and losses in the ocean. Nature, 2007, $445: 163-167$. 